УДК [378.091.12.011.3 - 051:373.3]:745/749

UDC [378.091.12.011.3 - 051:373.3]:745/749

DOI: 10.31475/ped.dys.2018.25.07

ГАЛИНА БУЧКІВСЬКА,

кандидат педагогічних наук, доцент, докторант

(Украйна, Тернопіль, Тернопільський національний педагогічний університет ілені Володимира Гнатюка,вул. М. Кривоноса, 2)

GALYNA BUCHKIVSKA, candidate of pedagogical sciences, associate professor, postdoctoral student (Ukraine, Ternopil, Ternopil Volodymyr Hnatiuk National Pedagogical University, M. Kryvonosa Str., 2)

ORCID: 0000-0002-4836-8280

\title{
Організаційно-педагогічні умови реалізації системи професійної підготовки майбутніх учителів початкових класів на засадах народного декоративно-ужиткового мистецтва
}

\section{Organizational and Pedagogical Sonditions of the System of Professional Education of Primary School Teachers on the Bases of Folk Decorative- and Applied Arts}

У статті визначено організаційно-педагогічні умови, які сприяють ефбективній реалізаціӥ педагогічної моделі професійної підготовки майбутніх учителів початкових класів на засадах народного декоративно-ужиткового мистеитва. Відібрано традиційні та інноваційні фборми, методи $i$ засоби навчання, впровадження яких сприяло глибокому розкриттю змісту інбборлаційно-пізнавального матеріалу, стимулюванню творчої активності, підвищенню мотивації студентів до вивчення народного декоративно-ужиткового мистеитва, використанню його виховного та культурно-освітнього потенціалу у майбутній проббесійній діяльності.

Розроблено методичні поради щодо створення організаційно-педагогічних умов для ефьективного фбункиіонування системи профбесійної підготовки майбутніх учителів початкових класів на засадах народного декоративно-ужиткового мистецтва, а також інструментарій для комплексного діагностування рівня готовності студентів до творчої художньо-трудової та профбесійної діяльності в початковій загальноосвітній школі.

Ключові слова: організаційно-педагогічні умови, народне декоративно-ужиткове мистеитво, творча художньо-трудова підготовка, культурно-освітне середовище, готовність до професійної діяльності, майбутні вчителі початкових класів.

The article attempts to analyze the influence of means of national culture, in particular folk decorative-applied arts, on the formation of a creative teacher, his or her aesthetic tastes and spiritualmoral values, ethnocultural self-identification and national consciousness.

The organizational and pedagogical conditions have been determined that promote the effective realization of the pedagogical model of vocational training of future teachers of elementary school on the basis of folk decorative and applied art (formation of students' motivation for the knowledge of ethnohistorical, spiritual and cultural heritage, embodied in works of folk decorative and applied arts, setting up of creative cultural and educational environment of professional preparation on the basis of folk arts and crafts; continuity of study of artistic and design-technological disciplines at all levels of training students in educational institutions of higher education; systematic involvement of students in extracurricular educational work based on folk arts and crafts). The author selected traditional and innovative forms, methods and means of teaching, the introduction of which contributed to the deeper disclosure of the content of information and cognitive material, stimulation of creative activity, increased motivation of students to study folk arts and crafts, the use of its educational, cultural and educational potential in future professional activity.

Develops methodical advice on creation of organizational and pedagogical conditions for efficient functioning of the system of future primary school teachers' professional training on the basis of folk decorative and applied arts, as well as a tool for complex diagnosing of the level of readiness of students for creative artistic, labor and professional activity in elementary secondary school.

Key words: organizational and pedagogical conditions, folk arts and crafts, creative artistic and labor training, cultural and educational environment, readiness for professional activity, future teachers of elementary school. 
Вступ / Introduction. Перші кроки інтеграції України до европейського освітнього простору супроводжуються передовсім оновленням змісту фахової підготовки вчителів початкових класів, що мае глибинний характер і потребуе розв'язання низки проблем становлення та розвитку педагога, який усвідомлюе свою професійну відповідальність, е людиною культури (а не лише джерелом і ретранслятором інформаціі), активно впливае на гармонійний розвиток і національну самосвідомість тих, кого навчае й виховуе. Тому в педагогічних закладах вищої освіти основним завданням освітнього процесу стає підготовка вчителя - творця, вихователя, фасилітатора, ментора, здатного вийти за межі шкільних предметів, стати для учнів початкових класів активним носіем національної культури і духовно-матеріальних традищій українського народу. В умовах сьогодення спостерігається стійка тенденція посилення уваги до підготовки модерного вчителя початкових класів, який має бути готовим до створення в школі різнобарвного етнокультурного освітнього середовища, своєрідного храму народного і сучасного мистецтва, в якому пануе історична пам'ять, культурний код і дух нації.

Отже, Нова українська школа потребує вчителів початкових класів з широким світоглядом, креативним мисленням, високим рівнем інтелекту та глибинними духовно-моральними якостями, який володіє інтегрованими знаннями етноісторичного, художньо-мистецького, проектнотехнологічного, психолого-педагогічного і методичного характеру, практичними уміннями та навичками з основних видів народного декоративно-ужиткового мистецтва, розвинутими творчими здібностями до художньо-трудової діяльності.

Незважаючи на те, що у вітчизняній науці е грунтовні педагогічні дослідження власне профресійної підготовки вчителів для початкової школи, наразі відсутне цілісне дослідження проблеми формування у ціеї категорії педагогічних працівників рис творчої особистості, національної самосвідомості, високого рівня компетентності засобами народного декоративноужиткового мистецтва. Тому актуальною постає необхідність вдосконалення професійної підготовки майбутніх учителів початкових класів для Нової української школи на засадах народного декоративно-ужиткового мистецтва та визначення їі організаційно-педагогічних умов відповідно до сучасних соціально-економічних, суспільно-політичних викликів та функціональностатусних потреб.

Мета та завдання / Aim and Tasks. Мета статті - визначити та розкрити організаційнопедагогічны умови реалізації системи професійної підготовки майбутніх учителів початкових класів на засадах народного декоративно-ужиткового мистецтва в умовах педагогічного закладу вищої освіти.

\section{Завдання дослідження:}

1) зясувати зміст поняття «педагогічні умови»;

2) виявити та теоретично обгрунтувати організаційно-педагогічні умови профресійної підготовки майбутніх учителів початкових класів на засадах народного декоративно-ужиткового мистецтва;

3) розробити методичні поради щодо створення організаційно-педагогічних умов для ефективного функціонування системи професійної підготовки майбутніх учителів початкових класів на засадах народного декоративно-ужиткового мистецтва.

Методи / Methods. Під час дослідження проблеми було використано такі методи: теоретичні (контент-аналіз; синтез емпіричного матеріалу з проблеми підготовки майбутнього вчителя початкових класів на засадах декоративно-ужиткового мистецтва, індукція, дедукція, аналогія, абстрагування, конкретизація, узагальнення); емпіричні (спостереження, анкетування, ранжування, тестування, експертне оцінювання) - для оббрунтування педагогічних умов професійної підготовки майбутніх учителів початкових класів на засадах народного декоративноужиткового мистецтва.

Результати / Results. Ефективне функціонування системи професійної підготовки майбутніх учителів початкових класів на засадах народного декоративно-ужиткового мистецтва зумовлюеться комплексом спеціально організованих заходів, що визначають необхідність дотримання відповідних організаційно-педагогічних умов.

$\mathrm{y}$ широкому філософському сенсі під умовою розуміють категорію, що виявляе відношення предмета до оточуючих його явищ, без яких він не може існувати; обставину, від якої щось залежить (Философский энциклопедический словарь, 1983); необхідну обставину, передумову, яка робить можливим здійснення чого-небудь; особливості реальної дійсності, при яких щось відбувається або здійснюеться (Івченко А., 2002); обставину, що зумовлюе появу / розвиток того чи іншого процесу (Новиков А., 2013).

Психологічною наукою термін «умова» трактуеться як сукупність внутрішніх і зовнішніх причин (чинників), котрі визначають психологічний розвиток людини, прискорюють або сповільнюють його динаміку та кінщевий результат (Немов Р., 2003); чинники, від яких залежить 
розвиток індивіда (Психологический словарь, 2007).

Відповідно до завдань дослідження необхідно з'ясувати зміст поняття «педагогічна умова» («організаційно-педагогічна умова») та виявити й теоретично обгрунтувати ті умови, які найефективніше забезпечать професійну підготовку майбутніх учителів початкових класів на засадах народного декоративно-ужиткового мистецтва.

У педагогіці, на відміну від філософії чи історії, умови не викликають появи певних подій, проте підсилюють або навпаки послаблюють дію причини такої появи. Відповідно до цього педагогічні умови визначаються як обставини, від яких залежить ефективність функціонування педагогічної системи. Пошуку ефективних педагогічних умов організації освітнього процесу присвячені наукові праці відомих вітчизняних i зарубіжних учених: Ю. Бабанського, В. Загвязинського, В. Краєвського, І. Лернера, С. Савельєвої та ін.

Педагогічні умови, на думку Ю. Бабанського, - це обставини, при яких компоненти освітнього процесу (навчальний предмет, викладання та навчання) представлені в найкращому взаемовідношенні та уможливлюють ефективний перебіг й управління навчально-пізнавальною діяльністю учнів (Бабанский Ю., 1982). Подібно І. Лернер розглядає педагогічні умови як чинники, котрі забезпечують успішність навчання (Лернер И., 1982). Під педагогічними умовами В. Краєвський розуміе певне середовище, в якому вчителеві (викладачеві) надається можливість проводити заняття на високому професійному рівні, ефективно керувати навчально-пізнавальним процесом, а учням (студентам) - продуктивно навчатися (Краевский В., 2005). Водночас В. Загвязинський розглядає педагогічні умови як об’ективні чинники, необхідні для результативної роботи всіх компонентів освітнього процесу (Загвязинский В., 1982). За С. Вишняковою, педагогічні умови - це сукупність чинників і обставин, які безпосередньо впливають на результат освітньої діяльності (Вишнякова С., 1999). Узагальнюючи дефініції різних учених, під педагогічними умовали розумітимемо комплекс педагогічних заходів, спрямованих на підвищення ефбективності освітнього процесу.

Особливості предмету дослідження актуалізують не лише педагогічну, а й організаційну сторону освітнього процесу, оскільки від ефрективної організації та управління навчальнопізнавальною діяльністю студентів залежить якість професійної підготовки в цілому. У зв'язку з цим необхідно розглядати організаиійно-педагогічні улови, котрі забезпечують ефективну професійну підготовку майбутніх учителів початкових класів на засадах народного декоративноужиткового мистецтва.

У загальному під організаційно-педагогічнили уловали розулітилело сукупність зовнішніх чинників реалізації ббункиій управління з боку викладача та внутрішніх особливостей навчальної діяльності студентів, які колплексно забезпечують иілісність й ефбективність освітнього процесу, цілеспрялованість та результативність їхньої профбесійної підготовки на засадах народного декоративно-ужиткового мистецтва.

Пошук й обтрунтування організаційно-педагогічних умов здійснювався відповідно до таких базових вихідних положень:

1) організаційно-педагогічні умови $е$ обов'язковим компонентом системи професійної підготовки майбутніх учителів початкових класів на засадах народного декоративно-ужиткового мистецтва й уможливлюють їі ефективність і результативність;

2) забезпечення належних організаційно-педагогічних умов пов'язане з впливом відповідних чинників: об’єктивних (характеризують процесуальну складову професійної підготовки студентів) та суб'єктивних (характеризують особистісні та професійні якості суб'єктів освітнього процесу);

3) організаційно-педагогічні умови передбачають виконання комплексу спеціальних заходів (організаційних, методичних, управлінських), необхідних для їх належного забезпечення.

Виявлення організаційно-педагогічних умов ефективного фрункціонування системи професійної підготовки майбутніх учителів початкових класів на засадах народного декоративноужиткового мистецтва здійснювалося з урахуванням специфіки освітнього процесу у педагогічному закладі вищої освіти, сутності творчої художньо-трудової діяльності студентів тощо. Крім цього, організаційно-педагогічні умови мають забезпечувати функціонування як окремих компонентів педагогічної системи, так і весь процес професійної підготовки студентів на засадах народного декоративно-ужиткового мистецтва.

Розгляд організаційно-педагогічних умов розвитку творчих здібностей студентів, запропонованих Л. Оршанським у монографії «Художньо-трудова підготовка вчителів трудового навчання», показав, що їх перелік є доволі широким: 1) створення творчої атмосфери на заняттях; 2) впровадження відкритих методів навчання; 3) правильна послідовність залучення студентів до творчої художньо-трудової діяльності; 4) запровадження педагогічного обмеження навчального завдання творчого характеру при різноманітності варіантів його розв'язання; 5) використання аналогії як основного шляху активізації творчого мислення; 6) обов'язковий поділ студентської 
групи на підгрупи для виконання завдань творчого характеру; 7) «матеріалізація» та пропагування творчих результатів студентів; 8) об'єктивність і доброзичливість в оцінюванні творчих задумів студентів (Оршанський Л., 2008). Наш багаторічний досвід викладацької роботи у педагогічному закладі вищої освіти свідчить, що в процесі експериментального дослідження складно перевірити ефективність великої кількості організаційно-педагогічних умов та з'ясувати, які з них найбільше впливають на творчу художньо-трудову підготовку студентів.

Зважаючи на вище зазначене, нами виокремлено лише чотири, 3 нашого погляду, основні організаційно-педагогічні умови едективного фрункціонування системи професійної підготовки майбутніх учителів початкових класів на засадах народного декоративно-ужиткового мистецтва, а саме: 1) формування мотивації студентів до пізнання етноісторичної, духовно-культурної спадщини, втіленої у творах народного декоративно-ужиткового мистецтва; 2) створення креативного культурно-освітнього середовища профресійної підготовки на засадах народного декоративно-ужиткового мистецтва; 3) наступність вивчення художньо-мистецьких i проектнотехнологічних дисциплін на всіх рівнях професійної підготовки студентів у педагогічному закладі вищої освіти; 4) систематичне залучення студентів до позааудиторної навчально-виховної роботи на засадах народного декоративно-ужиткового мистецтва.

Дамо загальну характеристику цим організаційно-педагогічним умовам.

1. Форлування мотивації студентів до пізнання етноісторичної, духовнокультурної спадицни, втіленої у творах народного декоративно-уюсткового мистецтва. Однією з умов успішної навчально-пізнавальної діяльності студентів, пов'язаної 3 вивченням народного декоративно-ужиткового мистецтва, є готовність студентів до сприйняття, осмислення та засвоєння відповідного предметного змісту. Беззаперечною є теза про те, що результативність навчання суттєво залежить від ставлення студентів до навчально-пізнавальної діяльності. Свого часу відомий вітчизняний педагог К. Ушинський писав, що «навчання, позбавлене всякого інтересу й організоване силою примусу, «вбиває» бажання вчитися, без якого неможливе успішне просування на шляху пізнання» (Ушинский К., 1989). Отже цілеспрямоване формування стійкого інтересу студентів, зокрема й до народного декоративно-ужиткового мистецтва, має важливе значення у процесі професійної підготовки.

Передумовою розвитку інтересу у студентів є формування мотивації до навчання, тобто спрямованості їхньої активності. Інтерес виступає похідною від стану мотивації, представляе інтегральний прояв різноманітних процесів мотиваційної сорери (Щукина Г., 1988).

Мотив - це рушійна сила дій і вчинків, основними функціями якої виступають активізуюча, контролююча та спрямовуюча. Мотив складається з мети (цілей) та програми дій, які сукупно утворюють механізм активізації будь-якої діяльності. Отже важливою характеристикою діяльності виступає iï вмотивованість. Будь-яка дія виходить із мотиву, тобто спонукаючого до дії переживання чогось значущого, що надає дії певного сенсу і важливості для індивіда (Соколова С., 2002).

Виокремлюючи рівні мотивацї до навчання, важливим є перехід від широкого навчального інтересу до пізнавального. При цьому обов'язковою умовою повнощінного навчання $\epsilon$ результативний інтерес. Для отримання кращого кінцевого результату необхідна виражена орієнтація студента на пошук ефективніших шляхів його досягнення, що визначає цінність інтересу до способів діяльності, їх удосконалення (Маркуцкая С., 1998).

Незважаючи на те, що під впливом навчальної діяльності відбуваються позитивні зміни в системі мотиваційно-ціннісної орієнтації студентів, однак залежно від індивідуальних особливостей можуть домінувати різні мотиви до творчої діяльності, у т.ч. художньо-трудової. Здійснюючи експериментальну перевірку мотиваційних чинників творчої активності, Д. Богоявленська доводить ефективність пізнавальних мотивів, при яких діяльність людини зорієнтована на «внутрішні» критерії оцінки успішності, тобто на цінність творчого процесу для неї самої. Водночас вона зазначає, що престижні мотиви, які орієнтують людину лише на заохочення, перемогу в змагальності, самоствердження можуть гальмувати творчий розвиток індивіда (Богоявленская Д., 1981). Таким чином, фрормування мотиваційної структури на основі вищих духовних потреб i широких соціально зумовлених інтересів (етноісторичних, культурномистецьких, національно-патріотичних та ін.) виступає важливим чинником формування творчої особистості майбутніх учителів початкових класів.

Потреби і мотиви студентів мають бути скеровані не лише на навчальну діяльність як процес, a й на об’єкти пізнання (твори народного декоративно-ужиткового мистецтва), зокрема їх художній зміст, культурну та мистецьку цінність. Отже, навчання неодмінно має бути виховуючим, тобто формувати позитивне ставлення майбутніх учителів початкових класів до духовно-культурної спадщини українського етносу, що сприяє формуванню відповідної системи цінностей i переконань. 
У процесі засвоєння художньо-мистецьких і проектно-технологічних дисциплін у студентів формуеться потреба «занурення» в народне декоративно-ужиткове мистецтво, що породжуе не лише його естетичне сприйняття, а й стимулюе до самостійної творчої художньо-трудової діяльності. 3 метою формування у студентів стійкої мотивації до навчання художньо-мистецьких і проектно-технологічних дисциплін, що дає змогу займатися не лише цікавою і корисною справою,

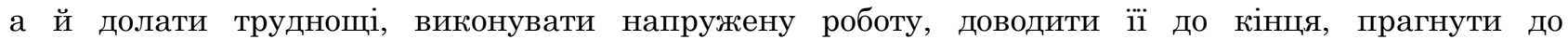
досконалості, «необхідно, щоб їні мотиви і потреби в процесі інтеріоризації стали особистісно значущими інтересами, переконаннями, цінностями» (Моляко В., н.д.).

Безпосередній процес творчої художньо-трудової діяльності, можливість роботи з різними природними та конструкційними матеріалами, майстерне володіння художніми техніками вже викликае у студентів певний інтерес, стимулюе творчу активність, зумовлюе мотивацію до навчання. Відомий психолог Л. Виготський зазначав, що «підвищенню мотивації до навчання сприяе використання в освітньому процесі нових для учнів навчальних засобів (творів декоративно-ужиткового мистецтва, матеріалів, інструментів, художніх технік та ін.)» (Выготский Л., 1997), що найбільш ефективно можна зреалізувати у процесі творчої художньотрудової підготовки майбутніх учителів у педагогічному закладі вищої освіти.

Тому, важливим $е$ добір об’ектів - декоративно-ужиткових виробів - для вивчення майбутніми вчителями початкових класів. Об'єкти мають приваблювати студентів високим художньоестетичним рівнем, майстерністю виконання, забезпечувати можливість розглянути основні правила, прийоми і засоби композиційних й орнаментальних побудов, особливості використання кольорової гами, проектування форми тощо. В них мають найбільш яскраво проявлятися виражальні та пластичні характеристики матеріалу та технології його обробки. Добір об’ектів (декоративно-ужиткових виробів) визначається за такими принципами: художньо-естетична цінність; технологія виготовлення, вид художньої обробки; відповідність естетичного сприйняття реальній художньо-трудовій діяльності студентів та ін.

Важливе значення для підвищення мотивації до творчої художньо-трудової діяльності має демонстрування кращих робіт (декоративно-ужиткових виробів) студентів попередніх років. Це дає змогу показати високий рівень професійної підготовки студентів, практичну значущість ії результатів, яких можна досягти у процесі навчання у педагогічному закладі вищої освіти.

Вихованню стійкого інтересу i, відповідно, мотивації до навчання сприяе використання комплексу завдань, розв'язання яких потребуе від студентів активної пошукової діяльності, а також включення у зміст лекцій чи практичних занять творчих, імпровізаційних запитань i проблемних задач. При цьому ефективність оволодіння новим матеріалом зростае, якщо підбір змісту навчальних завдань здійснюеться з опорою на попередньо засвоєні знання й уміння студентів із художньо-мистецьких і проектно-технологічних дисциплін. Опора на існуючу систему знань дає змогу досягти міцного засвоєння нового матеріалу, уможливлюе послідовне зростання складності навчальних завдань, підвищення вимог до професійної підготовки студентів, сприяе виникненню пізнавального інтересу.

Завдання викладача полягае у реалізації педагогічного впливу на систему мотиваційноціннісних орієнтацій студентів, при якому їх особистісна спрямованість буде відображати суспільно значущі цінності, ідеали та потреби. Суспільно необхідні мотиви діяльності передбачають ставлення до навчання з почуттям обов'язку, відповідальності, ініщіативності. Суспільні вимоги до рівня професійної підготовки майбутніх учителів початкових класів мають стимулювати студентів не лише до належного засвоєння змісту художньо-мистецьких і проектно-технологічних дисциплін, а й високого рівня ерудованості, всебічного розвитку, одержання знань, які виходять за межі змісту робочих навчальних програм. Доведення до свідомості студентів сутності суспільного ідеалу вчителя як професіонала, майстра своєї справи, творчої особистості, мають сприяти виникненню у майбутніх педагогів прагнення йому відповідати, породжуе мотивацію до навчання. Тому проектуючи зміст професійної підготовки на засадах народного декоративно-ужиткового мистецтва, важливим є врахування його спрямованості на майбутню професійно-педагогічну $\mathrm{i}$ художньо-творчу діяльність майбутніх учителів початкових класів.

Таким чином, важливим завданням викладача стає врахування, коригування, а за необхідності й формування потреб і мотивів студентів у процесі професійної підготовки, зокрема у вивченні художньо-мистецьких і проектно-технологічних дисциплін. Цьому сприяе низка заходів:

1) попередня підготовка студентів до занять (підбір необхідних матеріалів, інструментів та пристосувань; вивчення спеціальної мистецької літератури; ознайомлення зі зразками декоративно-ужиткових виробів та ін.);

2) активне ознайомлення у процесі вивчення художньо-мистецьких дисциплін із творами народного декоративно-ужиткового мистецтва, передовсім характерними для регіону проживання i навчання студентів; 
3) стимулювання інтересу студентів до народного декоративно-ужиткового мистецтва у процесі широкої позааудиторної діяльності (консультації; майстер-класи; зустрічі з народними майстрами; екскурсії на підприемства художньої промисловості та краезнавчі музеї, виставки народного декоративно-ужиткового мистецтва, етнографічні експедиції та ін.);

4) перманентна зміна видів народного декоративно-ужиткового мистецтва у процесі творчої художньо-трудової діяльності студентів;

5) раціональне поєднання індивідуальних і колективних форм творчої художньо-трудової діяльності студентів;

6) включення у зміст суміжних навчальних дисциплін матеріалу мистецтвознавчого характеру.

2. Створення креативного культурно-освітнього середовища профбесійної підготовки на засадах народного декоративно-ужиткового листецтва. Навчальна діяльність постає як процес засвоення необхідних знань й умінь, які в реальних умовах не завжди відповідають рівневі індивідуальної підготовленості студентів. Тому одним із можливих шляхів підвищення ефективності освітнього процесу $є$ надання кожному студентові свободи вибору, простору для реалізації творчого потенціалу. Відкритість до нового у поєднанні з бажанням навчатися і високою самооцінкою, впевненістю у собі сприяе створенню креативного освітнього середовища, спрямованого на досягнення майбутніми вчителями початкових класів високого рівня творчої активності та пізнавальної самостійності.

Важливість створення креативного культурно-освітнього середовища професійної підготовки на засадах народного декоративно-ужиткового мистецтва підтверджуеться специфікою творчої художньо-трудової діяльності, яка в силу різних обставин постійно змінюеться й удосконалюеться, що вимагае від студентів постійного прояву креативності, творчих здібностей й умінь, розкриття творчого потенціалу. При цьому важливою складовою творчої художньо-трудової діяльності стає здатність і готовність майбутніх учителів початкових класів до ії ефективної реалізації в умовах загальноосвітньої школи.

Готовність у цьому контексті визначається системою знань, умінь і навичок майбутнього вчителя, необхідних для самостійного, ефективного i креативного розв'язання професійнопедагогічних завдань, зокрема у процесі творчої художньо-трудової діяльності молодших школярів. Водночас здатність розглядаеться як спроможність вчителя самостійно створювати засоби і способи досягнення поставлених цілей.

Професійно компетентний вчитель постає як мобільний суб’єкт, що володіє особливою особистісною позицією вільного вибору виду, способів і форм діяльності; здатний до професійного саморозвитку в умовах динамічного інформаційного суспільства. Реалізація творчої активності у процесі професійної діяльності (зокрема художньо-трудової), створення креативного культурноосвітнього середовища, розробка відповідних технологій навчання i виховання сприяе самореалізації, розкриттю індивідуальних особливостей та потенщійних можливостей майбутнього вчителя початкових класів. Творчість проявляеться в готовності вчителя до інноваційних процесів, нових типів професійних відносин, самовираження у проблемних ситуаціях. Показником педагогічної творчості, на думку В. Слатьоніна (Сластенин В., 1976) стае здатність вчителя модифікувати, комбінувати, адаптувати власну професійну діяльність відповідно до нестандартного характеру освітнього процесу.

Якісний показник професійної діяльності майбутніх учителів початкових класів на засадах народного декоративно-ужиткового мистецтва напряму залежить від рівня сформованості творчого потенщіалу студентів. Максимальний творчий розвиток особистості майбутнього педагога можливий під впливом освітньо-культурного середовища, яке крім предметно-інформаційного змісту про сутність і різновиди народного декоративно-ужиткового мистецтва передбачає активнокреативний характер художньо-трудової діяльності студентів.

Креативне освітньо-культурне середовища професійної підготовки майбутніх учителів початкових класів на засадах народного декоративно-ужиткового мистецтва створюеться шляхом використання в освітньому процесі комплексу завдань і творчих проектів, оцінювання результатів творчої діяльності тощо. Важливе значення при цьому має стимулювання у студентів впевненості у власних силах, позитивних емоцій, подолання відчуття страху за можливі помилки при розробці проектів декоративно-ужиткових виробів та використанні технологій їх виготовлення чи художніх технік, створення комфортної атмосфери успіху. Процес самоствердження студентів у процесі творчої художньо-трудової діяльності вимагае постійної активізації позитивних емоційних станів, зокрема через стимулювання пізнавального інтересу, допитливість, створення проблемних ситуацій, організацію змагальності та ін.

Створенню креативного освітньо-культурного середовища сприяе використання активних $\mathrm{i}$ частково-пошукових (евристичних) методів навчання, які стимулюють студентів до самостійної 
художньо-трудової діяльності, відкриття нових знань про народне декоративно-ужиткове мистецтво, посилюють впевненість у власних творчих здібностях. У процесі творчої художньотрудової діяльності створюються найкращі умови для розвитку розумової активності та самостійності особистості, спрямованої на відкриття студентом чогось нового у галузі народного декоративно-ужиткового мистецтва, створення нових, оригінальних форм виробів, розроблення оригінальних орнаментальних композицій. Відповідно до цього, процес підготовки студентів до творчої художньо-трудової діяльності доцільно здійснювати поетапно: на першому етапі забезпечуеться розвиток інтелектуальних й особистісних якостей студентів, на другому здійснюеться засвоєння елементів творчої діяльності (прийомів, методів розв'язання творчих завдань, пошуку творчих рішень нових форм декоративно-ужиткових виробів та ін.), на третьому відбуваеться практичне використання набутих знань й умінь, досвіду творчої художньо-трудової у процесі виконання творчих проектів і втілення їх у матеріалі.

Створення креативного культурно-освітнього середовища професійної підготовки на засадах народного декоративно-ужиткового мистецтва грунтується на певній психологічній і соціальній готовності особистості викладача, яка дае змогу змінювати (коригувати) наявні педагогічні ситуації з метою забезпечення усім суб’ектам освітнього процесу ефективної творчої взаемодії, досягнення взаеморозуміння при розробленні творчих проектів, максимального виключення появи можливих непорозумінь і конфліктних ситуацій.

Організація навчальної діяльності на засадах творчості є важливою умовою створенню креативного освітньо-культурного середовища у педагогічному закладі вищої освіти, що сприяе розвитку професійної компетентності студентів, зокрема за рахунок використання потенщіалу художньо-мистецьких і проектно-технологічних дисциплін, раціонального поєднання форм i методів активного та інтерактивного навчання, розв’язання художньо-проектних, технікотехнологічних і методичних завдань.

Створенню креативного середовища професійної підготовки майбутніх учителів початкових класів на засадах народного декоративно-ужиткового мистецтва сприяе сукупність таких чинників:

1) забезпечення професійно-педагогічної спрямованості художньо-мистецьких i проектнотехнологічних дисциплін;

2) стимулювання та підтримування постійного інтересу до творчої художньо-трудової діяльності у галузі народного декоративно-ужиткового мистецтва;

3) оволодіння методами самостійної роботи студентів над проектами декоративно-ужиткових виробів;

4) систематичний контроль за творчою художньо-трудовою діяльністю студентів, встановлення інтенсивності та напряму освітнього процесу, забезпечення успішної групової комунікації з боку викладачів як фасилітаторів і менторів;

5) імітація реальних творчих процесів з проектування і виготовлення декоративно-ужиткових виробів, а також профресійно-педагогічних ситуащій, пов'язаних із навчання молодших школярів різним видам народного декоративно-ужиткового мистецтва;

6) створення макро- та мікроклімату для прояву творчості студентів у пошуку форм, підбору кольорової гами, розробленні схем орнаментальних композицій;

7) спільний (груповий) пошуковий характер творчої художньо-трудової діяльності студентів;

8) створення ситуацій актуалізації креативності студентів, зокрема через розв'язування творчих професійно-орієнтованих завдань;

9) використання індивідуальної системи художньо-творчих завдань 3 проектування та виготовлення декоративно-ужиткових виробів.

Важливе значення для створення креативного культурно-освітнього середовища професійної підготовки на засадах народного декоративно-ужиткового мистецтва має розв’язування художньотворчих завдань. При цьому можливі такі особливості організації цієї діяльності студентів:

1. Навчальна проблема актуалізуеться перед усіма студентами групи 3 наступним обговоренням алгоритму їі розв'язання (обговорюеться ідея декоративно-ужиткового виробу, його утилітарне і декоративне значення, розглядається технологія виготовлення й оздоблення, здійснюеться добір необхідних матеріалів, інструментів, пристроїв та ін.).

2. Колективно намічається план дій (алгоритм розв'язання навчального завдання), встановлюються напрями творчого пошуку. При цьому пошукові дії кожен студент виконуе самостійно.

3. Творче завдання розв'язує кожен студент. Після цього здійснюється його колективне обговорення, визначаеться найбільш ращіональний спосіб розв'язання або синтезуються декілька оптимальних варіантів.

4. Загальне творче завдання розчленовуеться на окремі складові (підзавдання), які розподіляються між усіма учасниками групи. Кожен студент самостійно працюе над пошуком 
розв’язання свого підзавдання, вносячи індивідуальний вклад у спільну справу.

5. Творче завдання розв'язуеться частинами у мікрогрупах (3-5 студентів).

Управління творчою художньо-трудовою діяльністю студентів з боку викладача передбачає таку послідовність взаємопов'язаних дій:

- постановку й обтрунтування навчального завдання (проблеми), що містить суб’ективну новизну для студентів;

- спрямування мисленневої діяльності студентів на з'ясування алгоритму художньомистецької та проектно-технологічної діяльності, формування установки на виконання завдання;

- надання студентам своєчасної консультації у процесі художнього проектування та виготовлення декоративно-ужиткових виробів;

- здійснення контролю за творчою художньо-трудовою діяльністю студентів, оцінювання ії кінцевих результатів.

3. Наступність вивчення художньо-листецьких $і$ проектно-технологічних дисциплін на всіх рівнях професійної підготовки студентів у педагогічнолу закладі вищої освіти. Ефективність професійного становлення майбутніх учителів початкових класів на засадах народного декоративно-ужиткового мистецтва зумовлюеться узгодженістю, взаємозв’язком і наступністю основних етапів творчої художньо-трудової підготовки студентів у педагогічному закладі вищої освіти. Зміни, що відбуваються у системі професійної підготовки педагогічних працівників (зокрема художньо-трудової підготовки вчителів початкової ланки освіти), реалізація iï неперервності, диференціація й інтеграція структур забезпечуються наступністю її етапів.

Під наступністю необхідно розуміти оптимальну послідовність і семантичний зв'язок у системі змісту навчального матеріалу, методів і дидактичних засобів навчання, які забезпечують максимальну ефективність професійної підготовки в умовах розвитку сучасного інформаційного суспільства (Машиев Ч., 2004).

Великого значення наступності у навчанні надавав К. Ушинський, який розглядав засвоєння нових знань, як процес встановлення зв'язку зі старими (вже сформованими) знаннями, незалежно від того, з якого предмету і коли вони були набуті. На думку вченого, не може бути жорсткої межі між новими і старими знаннями, тому встановлення зв'язків між ними постає важливою умовою ефективності навчання (Ушинский К., 1989). В. Мадзігон розглядае наступність як психологопедагогічний принцип, який забезпечуе навчальний процес у чіткій системності з урахуванням оптимальних результатів розвитку здібностей суб'єктів навчання (Мадзигон В., 1975). О. Мороз застерігае, що відсутність наступності між окремими етапами навчання призводить до зниження рівня засвоєння учнями знань й умінь. Водночас учений підкреслюе, що вимогу наступності не можна обмежувати лише процесом навчання, це - загальнопедагогічна вимога. Забезпечення наступності у навчанні означае: постійний нерозривний зв'язок як між окремими частинами, етапами і ступенями навчання, так і всередині них; розширення і поглиблення знань, набутих на попередніх етапах навчання; розгортання навчального процесу відповідно до змісту, форм i методів роботи з обов'язковим урахуванням якісних змін в особистості суб’єктів навчання (Мороз О., 1971).

Наступність вивчення художньо-мистецьких і проектно-технологічних дисциплін передбачае цілеспрямовану організаційно-педагогічну роботу та виявлення найбільш значущих соціальнопедагогічних чинників, які забезпечують сприятливі умови для переходу студентів на вищий освітній ступінь: ОКР «Молодший спеціаліст» $\rightarrow$ OC «Бакалавр» $\rightarrow$ OC «Магістр».

Наступність у навчанні характеризуеться осмисленням пройденого на новому, вищому рівні, підкріпленням наявних знань новими, розкриттям нових зв'язків, завдяки яким якість знань, умінь і навичок підвищуеться. Тому одним із головних напрямів у реалізації наступності є чітке узгодження змісту художньо-мистецьких і проектно-технологічних дисциплін як у межах освітньої програми (навчального плану), так i між освітніми ступенями підготовки студентів у педагогічному закладі вищої освіти. При цьому наступність має забезпечувати не лише засвоєння знань й умінь у галузі народного декоративно-ужиткового мистецтва, а й підвищувати загальний рівень професійної підготовки студентів, розвиток особистісних якостей майбутніх учителів початкових класів, реалізувати функщію неперервності в навчанні та здобутті педагогічної освіти.

В основу забезпечення раціональної наступності вивчення художньо-мистецьких і проектнотехнологічних дисциплін майбутніми учителями початкових класів покладено концепції оптимальної структури процесу навчання (Ю. Бабанський), проблемного (М. Махмутов) та розвивального навчання (В. Давидов, Є. Кабанова-Меллер).

Наступність вивчення художньо-мистецьких і проектно-технологічних дисциплін як цілісна система передбачае едність усіх компонентів професійної підготовки студентів у педагогічному закладі вищої освіти, зорієнтованих на досягнення основної мети - формування готовності майбутніх учителів до професійної художньо-трудової діяльності у початковій школі. При цьому, 


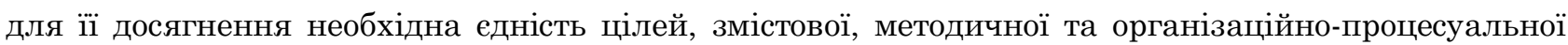
сторін процесу наступності. Між усіма компонентами наступності вивчення художньо-мистецьких і проектно-технологічних дисциплін існують зв'язки та залежності.

Наступність вивчення художньо-мистецьких і проектно-технологічних дисциплін розглядається у трьох аспектах:

1. Злістовий аспект забезпечуеться загальнопрофресійною і художньо-трудовою підготовкою студентів, що передбачає ефективне використання етноісторичного, культурно-мистецького й освітнього потенщіалу народного декоративно-ужиткового мистецтва у процесі розв'язання актуальних навчально-виховних завдань у початковій школі. Змістовий аспект наступності проявляється в узгодженості змісту освіти (Державний стандарт початкової освіти (освітні галузі «Мистецтво» та «Технології»), Профресійний стандарт «Вчитель початкових класів закладу загальної середньої освіти», освітні програми, програми навчальних дисщиплін, підручники, посібники та ін.) на всіх рівнях професійної підготовки студентів у педагогічному закладі вищої освіти. До характерних ознак змістової наступності у навчанні відносять: використання на кожному наступному етапі (рівні) навчання знань, умінь і навичок, набутих на попередньому етапі, тобто актуалізація опорних освітніх результатів; пропедевтичний характер навчання, тобто можливість на кожному етапі закладати основи навчання на наступному рівні.

2. Проиесуальний аспект забезпечується широким застосуванням технологій проблемного та розвивального навчання, методів і прийомів, що сприяють розвитку самостійності та пізнавальної активності студентів. Основними ознаками процесуальної наступності є взаємозв'язок між методами і засобами навчання, ращіональний підбір та послідовне застосування педагогічних технологій, які забезпечують розвиток творчих здібностей студентів у процесі художньо-трудової діяльності.

3. Організаиійний аспект забезпечуеться раціональним поєднанням різних фрорм проведення занять в умовах аудиторної та позааудиторної навчально-виховної роботи студентів (зокрема на базі музею народного декоративно-ужиткового мистецтва, в майстернях народних умільців тощо); проходженням педагогічної практики у початковій школі, де головна увага зосереджується на навчанні учнів молодших класів різним видам народного декоративно-ужиткового мистецтва.

4. Систелатичне залучення студентів до позааудиторної навчально-виховної роботи на засадах народного декоративно-уюситкового листецтва. Ефективне фрункціонування системи професійної підготовки майбутніх учителів початкових класів на засадах народного декоративно-ужиткового мистецтва забезпечується систематичною позааудиторною навчально-пізнавальною діяльністю, що постає важливим чинником особистісного творчого розвитку студентів i спрямована на їхне самовираження, самоствердження, профресійний саморозвиток.

Світоглядна орієнтація позааудиторної навчально-виховної роботи зумовлюеться особливим значенням народного декоративно-ужиткового мистецтва в соціалізації особистості, формуванні їі духовності; спрямованістю на загальнолюдські гуманістичні цінності та художнє осмислення естетичних проявів об'єктивної реальності. Емоційне «спілкування» 3 творами народного декоративно-ужиткового мистецтва допомагає студентам осмислити себе, свою роль і місце в сучасному світі та розвитку національної культури.

Основною метою всієї системи позааудиторних навчально-виховних заходів є розширення i поглиблення знань й уявлень студентів про народне декоративно-ужиткове мистецтво, розвиток здатності розуміти і відчувати прекрасне в навколишній дійсності.

Основні навчально-виховні завдання, які розв'язуе позааудиторна робота в царині народного декоративно-ужиткового мистецтва, полягають, по-перше, у вихованні емоційно-естетичного ставлення студентів до автентичних творів народного декоративно-ужиткового мистецтва; подруге, у розвитку художньо-творчих здібностей студентів відповідно до їх індивідуальних особливостей; по-трете, у розширенні знань з історії становлення та розвитку центрів народних художніх ремесел і промислів, морфології видів народного декоративно-ужиткового мистецтва, еволющії форм і стилістики в українські орнаментищі та ін.; вдосконаленні вмінь і навичок художнього проектування та виготовлення декоративно-ужиткових виробів.

Цінність позааудиторних навчально-виховних заходів зумовлюеться вищим «ступенем свободи» до їх планування, організації і проведення, підборі методичного інструментарію, доборі творчих завдань та відповідних художніх технік і технологій виготовлення декоративно-ужиткових виробів; широкими можливостями для індивідуалізації художньо-трудової діяльності студентів, урізноманітненням форм стимулювання майбутніх педагогів до вивчення народного декоративноужиткового мистецтва.

Сприйняття творів народного декоративно-ужиткового мистецтва у процесі позааудиторної навчально-виховної роботи не повинно зводитися до простого накопичення у студентів відповідних 
уявлень і знань, його необхідно співвідносити з багатством діяльнісних проявів особистості (Ганнусенко Н., 2004). Слід наголосити, що у творах народного декоративно-ужиткового мистецтва матеріалізовано історичну пам'ять народу, яка крізь століття переносить уявлення про прекрасне, добре, вічне та протистоїть руйнівній силі часу і забуття. Ознайомлення студентів із народним декоративно-ужитковим мистецтвом має здійснюватися відповідно до концепції художнього твору, в основі якого лежить розуміння нерозривної едності образу і світосприйняття творця (майстра), зв’язок із природою, побутом, працею, історією й національними традиціями. Це сприяе розширенню світогляду майбутніх учителів, формуванню духовно-моральних якостей особистості, розвивае художній смак, виховуе любов до творчої діяльності тощо.

Основними підходами до організації позааудиторної навчально-пізнавальної діяльності студентів е: 1) оріентація на розширення предметного змісту народного декоративно-ужиткового мистецтва, виявлення, розкриття, поглиблення художніх інтересів і потреб особистості, розкриття творчого потенціалу, розвиток здібностей i нахилів студентів; 2) забезпечення студентам можливості не лише пасивного споглядання i сприйняття творів народного декоративноужиткового мистецтва чи практичної реалізації творчих задумів у проектах декоративноужиткових виробів, а й організації пошуково-дослідницької діяльності, яка забезпечуе розвиток особистості студента на самому високому рівні творчості.

До основних форм позааудиторної навчально-виховної роботи у процесі професійної підготовки майбутніх учителів початкових класів на засадах народного декоративно-ужиткового мистецтва належать: консультації, виконання студентами творчих проектів, курсових i випускових кваліфікаційних робіт; зустрічі 3 народними майстрами, художниками-прикладникаим, дизайнерами; екскурсії на підприемства художньої промисловості, в краезнавчі музеї; проведення етнофестивалів і свят, присвячених різним видам народного декоративно-ужиткового мистецтва; організація короткотривалих етнографрічних експедицій з вивчення історії житла, одягу, харчування, родинного укладу, форм побуту українців, дослідницька робота у фондах музеїв та ін.

Зокрема, у Хмельницькій гуманітарно-педагогічній академії студенти спеціальності 013 «Початкова освіта» (спеціалізація «Трудове навчання») активно залучаються до поповнення експозицій музею народного декоративно-ужиткового мистецтва, розширення його виставкового фонду студентськими творчими роботами. У процесі позааудиторної навчально-пізнавальної діяльності майбутні педагоги здійснюють пошук, узагальнення та систематизацію матеріалів пошуково-дослідницького характеру, проводять збір і дослідження об'єктів духовно-матеріальної культури Подільського краю.

Музей народного декоративно-ужиткового мистецтва у Хмельницькій гуманітарнопедагогічній академії працюе за такими експозиційними напрямами: народний одяг, фольклорна лялька, вишивка, писанкарство, декоративний розпис, художня обробка шкіри, художня обробка деревини, витинанка, вузликове плетіння, гончарство, народна іграшка та ін. У приміщенні музею постійно організовуються різні види позааудиторної навчально-виховної роботи студентів, зокрема пов'язані 3 підготовкою студентів до практичних занять, виконанням творчих проектів, написанням курсових і випускових (кваліфікаційних) робіт. При музеї створені школи-студії 3 етнодизайну та народних художніх ремесел, функціонують гуртки подільської вишивки, писанкарства, витинанки, народної ляльки та ін.

Тісна взаемодія між аудиторною та позааудиторною навчально-пізнавальною роботою студентів у музеї здійснюеться через використання елементів музейної педагогіки в освітньому процесі, залучення студентів до пошуково-дослідницької діяльності, виявлення їх творчого потенціалу в створенні експозиційного матеріалу та формуванні музейних фондів. Використання музейної педагогіки здійснюе не лише цілеспрямований виховний вплив на особистість студентів, iï гармонійний розвиток, а й дозволяе пов'язати цей процес із майбутньою професійнопедагогічною діяльністю у початковій школі.

Вибір організаційно-педагогічних умов ефективного функціонування системи професійної підготовки майбутніх учителів початкових класів на засадах народного декоративно-ужиткового мистецтва зумовлений їх практичною реалізаціею, що сприяе розкриттю творчого потенціалу особистості студентів, урахуванню їхніх інтересів, здібностей, можливостей, розвитку суб’єктної позиції. Це створюе надійне пвдгрунтя для ефективного формування професійної компетентності майбутніх учителів початкових класів, зокрема їхньої готовності до організацій та здійснення творчої художньо-трудової діяльності у початковій школі.

Окреслені організаційно-педагогічні умови та чинники ефективного функціонування системи професійної підготовки майбутніх учителів початкових класів на засадах народного декоративноужиткового мистецтва повинні перебувати у системній взаємодії та реалізуватися лише комплексно.

Обговорення / Discussion. У науково-педагогічній літературі зустрічаються різні погляди 
вчених щодо типології педагогічних (організаційно-педагогічних) умов, залежно від ознак, покладених в основу їх систематизаціі. Так, Є. Яковлев пропонуе таку класифікацію педагогічних умов (Яковлев Е., Яковлева Н., 2009): 1) за характером ключових чинників: зовнішні, внутрішні; 2) за типом діяльності суб’єктів навчання: організащійні, змістові, методичні; 3) за видом забезпечення освітнього процесу: матеріально-технічні, навчально-методичні, психологопедагогічні, санітарно-гігієнічні. Своєю чергою О. Новіков наголошує на умовах, визначальних для будь-якого виду людської діяльності: мотиваційні, кадрові, матеріально-технічні, науковометодичні, фрінансові, організащійні, нормативно-правові, інформаційні (Новиков А., 2013).

Виокремлюючи організаційно-педагогічні умови підвищення ефрективності освітнього процесу, В. Краєвський наголошує на матеріальних, психологічних і гігієнічних умовах (Краевский В., 2005). Подібно Ю. Бабанський підкреслюе важливість стану навчально-матеріального забезпечення освітнього процесу (матеріальні умови); роль зовнішніх впливів на суб'ектів навчання, стан морально-психологічного мікроклімату (психологічні умови) (Бабанский Ю., 1977).

Найбільш поширеною $є$ класифікація педагогічних (організащійно-педагогічних) умов на зовнішні та внутрішні (Ипполитова Н., Стерхова Н., 2012; Вільчинський В., 1991; Подласый И., 2006). Зовнішні умови визначають спрямованість освітнього процесу, його процесуальний бік (навчально-методичне, матеріально-технічне забезпечення, комплекс дидактичних засобів, технології навчання та ін.), а внутрішні - характеризують особистісний потенціал суб'єтів навчання, мотиваційно-ціннісну складову їхньої освітньої діяльності (індивідуальні особливості, здібності, задатки, цінності, переконання та ін.). При цьому зовнішні умови завжди перебувають у тісній взаємодії з внутрішніми, комплексно впливаючи на особистісний розвиток суб'єктів навчання.

Профресійна підготовка студентів за різними напрямами педагогічної діяльності має багато спільного, однак у цьому процесі завжди можна виокремити свої особливості. У зв'язку з цим, окремі вчені (Ю. Бабанський, В. Бондар, В. Краєвський, І. Малафрїк, О. Савченко та ін.) розмежовують педагогічні умови на загальні та спеціальні (особливі), наголошуючи на їх діалектичній єдності й взаємозв'язку.

Ефективність функціонування системи професійної підготовки майбутніх учителів початкових класів на засадах народного декоративно-ужиткового мистецтва зумовлюеться загальними й особливими (спеціальними) організаційно-педагогічними умовами, які забезпечують формування фрахівця як цілісної особистості, педагога-профресіонала. До загальних організаційно-педагогічних умов належать ті педагогічні чинники й обставини, які необхідні та достатні для нормального перебігу освітнього процесу у педагогічних закладах вищої освіти незалежно від напряму підготовки та спеціальності: належне кадрове, матеріально-технічне та навчально-методичне забезпечення освітнього процесу; сприятливий морально-психологічний клімат; відповідність навчальних приміщень санітарно-гігієнічним вимогам тощо.

Особливі (спеціальні) організаційно-педагогічні умови - це сукупність взаємопов'язаних i взаємозумовлених компонентів цілісного освітнього процесу, які забезпечують ефективну профресійну підготовку майбутніх учителів початкових класів на засадах народного декоративноужиткового мистецтва. У межах дисертаційного дослідження увага акцентуеться лише на особливих (спеціальних) організаційно-педагогічних умовах як ключових для ефрективного функціонування системи професійної підготовки майбутніх учителів початкових класів на засадах народного декоративно-ужиткового мистецтва.

Висновки / Conclusions. Ефективне фрункціонування системи профресійної підготовки майбутніх учителів початкових класів на засадах народного декоративно-ужиткового мистецтва зумовлюеться дотриманням відповідних організаційно-педагогічних умов. Під організаційнопедагогічними умовами нами розуміеться сукупність зовнішніх чинників реалізації фрункцій управління з боку викладача та внутрішніх особливостей навчальної діяльності студентів, які комплексно забезпечують цілісність й ефективність освітнього процесу, цілеспрямованість та результативність їхньої професійної підготовки на засадах народного декоративно-ужиткового мистецтва. У процесі дослідження нами визначено і схарактеризовано такі основні організаційнопедагогічні умови: 1) формування мотивації студентів до пізнання етноісторичної, духовнокультурної спадщини, втіленої у творах народного декоративно-ужиткового мистецтва; 2) створення креативного культурно-освітнього середовища профресійної підготовки на засадах народного декоративно-ужиткового мистецтва; 3) наступність вивчення художньо-мистецьких i проектно-технологічних дисциплін на всіх рівнях продессійної підготовки студентів у педагогічному закладі вищої освіти; 4) систематичне залучення студентів до позааудиторної навчально-виховної роботи на засадах народного декоративно-ужиткового мистецтва.

Дослідження підтвердило, що раціональне поєднання традищійних і сучасних, інноваційних форм організації, методів і засобів навчання дозволяе не лише активізувати освітній процес, 
домогтися глибокого розкриття змісту навчального матеріалу, а й підвищуе мотивацію майбутніх учителів початкових класів до вивчення народного декоративно-ужиткового мистецтва та використання його педагогічного потенціалу у майбутній професійній діяльності.

\section{Список використаних джерел і літератури / References}

1. Бабанский, Ю.К. (1977). Оптимизация процесса обучения (общедидактический аспект). Москва: Педагогика. / Babanskij, Yu. K. (1977). Optimizaciya processa obucheniya (obshhedidakticheskij aspekt) [Optimisation of Educational Process (General Didactic Aspect)]. Mosow: Pedagogika. [in Russian].

2. Бабанский, Ю.К. (1982). Проблемы повышения эфббективности педагогических исследований. Москва: Педагогика. / Babanskij, Yu.K. (1982). Problemy povysheniya e'ffektivnosti pedagogicheskix issledovanij [Problems of Encreasing Effectiveness of Pedagogical Researches]. Moscow: Pedagogika. [in Russian].

3. Богоявленская, Д.Б. (1981). Пути к твориеству. Москва: Знание. / Bogoyavlenskaya, D.B. (1981). Puti $k$ tvorchestvu [Ways to Creativity]. Moscow: Znaniye. [in Russian].

4. Вишнякова, С.М. (1999). Профбессиональное образование: Словарь. Ключевые понятия, термины, актуальная лексика. Москва: НМЦ СПО. / Vishnyakova, S.M. (1999). Professional'noe obrazovanie: Slovar'. Klyuchevye ponyatiya, terminy, aktual'naya leksika [Professional Education: Dictionary. Key Words, Terms, Topical Vocabulary]. Moscow: NMTS SPO. [in Russian].

5. Вільчинський, В.П. (1991). Образотворче мистецтво. 1-2 кл. Київ. / Vilchynskyi, V.P. (1991). Obrazotvorche mystetstvo. 1-2 kl. [Imitative Art. 1-2 Class]. Kyiv. [in Ukrainian].

6. Выготский, Л.С. (1997). Воображение и творчество в детском воздасте. А.Н. Драчева (Ред.). СанктПетербург: Союз. / Vygotskij, L.S. (1997). Voobrazhenie $i$ tvorchestvo $v$ detskom vozdaste [Imagination and Creativity in Early Age]. A.N. Dracheva (Red.). Sankt-Peterburg: Soyuz. [in Russian].

7. Ганнусенко, Н.I. (2004). Етнохудожне виховання школярів у позаурочний час [метод. реком.]. Київ: TOB «ХІК». / Hannusenko, N.I. (2004). Etnokhudozhnie vykhovannia shkoliariv u pozaurochnyi chas [Ethnocultural Education of Schoolchildren in Extracurricular Time]. [methodical recommendations]. Kyiv: TOV «KhIK». [in Ukrainian].

8. Загвязинский, В.И. (1982). Методология и методика дидактического исследования. Москва: Педагогика. / Zagvyazinskij, V.I. (1982). Metodologiya i metodika didakticheskogo issledovaniya [Methodology and Methods of Didactic Research]. Moscow: Pedagogika [in Russian].

9. Ипполитова, Н. и Стерхова, Н. (2012). Анализ понятия «педагогические условия»: сущность, классификация. General and Professional Education, 1. 8-14. Взято с http://genproedu.com/ paper/201201/full_008-014.pdf / Ippolitova, N. \& Sterxova, N. (2012). Analiz ponyatiya «pedagogicheskie usloviya»: sushhnost', klassifikaciya [Analysis of the Concept «Pedagogical Conditions»: Essence, Classification]. General and Professional Education, 1. 8-14. Retrieved from http://genproedu.com/paper/2012-01/full_008-014.pdf [in Russian].

10. Івченко, А. (2002). Тлумачний словник української мови. Харків: Фоліо. / Ivchenko, А. (2002). Tlumachnyi slovnyk ukrainskoi movy [Explanatory Dictionary of Ukrainian Language]. Kharkiv: Folio. [in Ukrainian].

11. Краевский, В.В. (2005). Общие основы педагогики [учеб. пособ.]. (2-е изд., испр.) Москва: Изд. центр «Академия». / Kraevskij, V.V. (2005). Obshhie osnovy pedagogiki [General Foundations of Pedagogy]. [textbook]. (2nd ed., revised.). Moscow: Izd. tsentr «Akademiya». [in Russian].

12. Лернер, И.Я. (1982). Процесс обучения и его закономерности. Москва: Знание. / Lerner, I.Yа. (1982). Process obucheniya i ego zakonomernosti [Process of Teaching and its Regularities]. Moscow: Znanie [in Russian].

13. Мадзигон, В.Н. (1975). Пути и средства усовершенствования преемственности в трудовом обучении учащихся общеобразовательных школ $u$ проббтех училищ (на материале электрорадиотехнических дисииплин). (Дис. канд. пед. наук). Киев. / Madzigon, V.N. (1975). Puti i sredstva usovershenstvovaniya preemstvennosti $v$ trudovom obuchenii uchashhixsya obshheobrazovatel'nyx shkol $i$ proftex uchilishh (na materiale e'lektroradiotexnicheskix disciplin) [Ways and Means of Mastering Succession in Labour Training of Students of General Educational Schools and Professional Colleges (on the Materials of ElectroRadiotechnical Disciplines)]. Candidate's thesis. Kyiv [in Russian].

14. Маркуцкая, С.Э. (1998). Методические основы обучения учащихся 5-7 классов прикладным художественныл работам в образовательной области "Технология». (Дис. канд. пед. наук). Москва. I Markuckaya, S.E'. (1998). Metodicheskie osnovy obucheniya uchashhixsya 5-7 klassov prikladnym xudozhestvennym rabotam v obrazovatel'noj oblasti "Texnologiya»[ Methodological Bases of Teaching Applied Artistic Works of the Pupils of 5-7 Classes in Educational Sphere]. Candidate's thesis. Moscow [in Russian].

15. Машиев, Ч.Г. (2004). Преелственность технологической подготовки в общеобразовательной и профбессиональной школе. (Дис. канд. пед. наук). Москва. I Mashiev, Ch.G. (2004). Preemstvennost' texnologicheskoj podgotovki v obshhe $\neg$ obrazovatel'noj $i$ professional'noj shkole [Succession of Technological Preparation in General-Educational and Professional School]. Candidate's thesis. Moscow, 2004. [in Russian].

16. Моляко, В.О. (б.д.). Психологія творчості - нова парадигма дослідження конструктивноі діяльності. Взято $\quad 3 \quad$ http://www.library.udpu.org.ual library_files/psuh_pedagog_probl_silsk_shkolu/6/visnuk_18.pdf / Moliako, V.O. (n.d.). Psykholohiia tvorchosti nova paradyhma doslidzhennia konstruktyunoi diialnosti [Psychology of Creativity - New Paradigm of Study of Constructive Activity]. Retrieved from http://www.library.udpu.org.ua/library_files/ psuh_pedagog_probl_silsk_shkolu/6/visnuk_18.pdf [in Ukrainian].

17. Мороз, О.Г. (1971). Шляхи здійснення наступності форм і методів навчання в середній та вищій школі. Вища і середня педагогічна освіта, 5, 88-93. / Moroz, O.H. (1971). Shliakhy zdiisnennia nastupnosti form 
i metodiv navchannia v serednii ta vyshchii shkoli [Ways of Conducting Succession of Forms and Methods of

Teaching in Secondary and Higher School]. Vyshcha i serednia pedahohichna osvita, 5, 88-93. [in Ukrainian].

18. Немов, Р.С. (2003). Психология: словарь-справочник. (Ч. 2). Москва: Изд. Владос-Пресс. / Nemov, R.S. (2003). Psixologiya: slovar'-spravochnik [Psychology: Dictionary-Manual]. (Part 2). Moscow: Izd. Vlados-Press. [in Russian].

19. Новиков, А.М. (2013). Педагогика: словарь системы основних понятий. Москва: Изд. центр ИЭТ / Novikov, A.M. (2013). Pedagogika: slovar' sistemy osnovnix ponyatij [Pedagogy : Dictionary of the System of Basic Concepts]. Moskva: Izd. centr IE'T [in Russian].

20. Оршанський, Л.В. (2008). Художньо-трудова підготовка вчителів трудового навчання [монографія]. Дрогобич: Коло. / Orshanskyi, L.V. (2008). Khudozhno-trudova pidhotovka vchyteliv trudovoho navchannia [Artistic-Labour Preparation of Labout Training Teachers]. [monograph]. Drohobych: Kolo [in Ukrainian].

21. Подласый, И.П. (2006). Педагогика: 100 вопросов - 100 ответов [учеб. пособ.]. Москва: Изд. Владоспресc. / Podlasyj, I.P. (2006). Pedagogika: 100 voprosov - 100 otvetov [Pedagogy: 100 Questions - 100 Answers]. [textbook]. Moscow: Izd. Vlados-press [in Russian].

22. Гуревич, П.С. (Ред). (2007). Психологический словарь. Москва: ОЛМА Медиа Групп, ОЛМА ПРЕСС Образование / Gurevich, P.S. (Ed.). (2007). Psixologicheskij slovar' [Psychological dictionary]. Moscow: OLMA Media Grupp, OLMA PRESS Obrazovanie [in Russian].

23. Сластенин, В.А. (1976). Формирование личности учителя советской школь в процессе профбессиональной подготовки. Москва: Просвещение / Slastenin, V.A. (1976). Formirovanie lichnosti uchitelya sovetskoj shkoly v processe professional'noj podgotovki [Formation of Personality of Teacher of Soviet School in the Process of Professional Training]. Moscow: Prosveshhenie [in Russian].

24. Сманцер, А.П. (2011). Теория и практика реализации преемственности в обучении школьников и студентов. Минск: БГУ. Взято с http://www.elib.bsu (дата обращения 12.10.2016) / Smancer, A.P. (2011). Teoriya i praktika realizacii preemstvennosti v obuchenii shkol'nikov $i$ studentov [Theory and Practice of Realization of Succession in Teaching Schoolchildren and Students]. Minsk: BGU. Retrieved from http://www.elib.bsu (last accessed 12.10.2016) [in Russian].

25. Соколова, С.Г. (2002). Подготовка учителей начальных классов $\kappa$ эстетическому воспитанию школьников на основе чувашского народного декоративно-прикладного искусства. (Дис. канд. пед. наук). Чебоксары. / Sokolova, S.G. (2002). Podgotovka uchitelej nachal'nyx klassov $k$ e'stetiches $\neg$ komu vospitaniyu shkol'nikov na osnove chuvashskogo narodnogo dekorativno-prikladnogo iskusstva [Preparation of Primary School Teachers to Aesthetic Education of Schoolchildren on the Basis of Chuvash Folk Decorative-Applied Art]. Candidate's thesis. Cheboksary [in Russian].

26. Ушинский, К.Д. (1974). Избранныее педагогические сочинения. (Т. 1). Москва: Педагогика. / Ushinskij, K.D. (1974). Izbrannye pedagogicheskie sochineniya [Selected Pedagogical Works]. (Vol. 1). Moscow: Pedagogika [in Russian].

27. Ушинский, К.Д. (1989). Педагогические сочинения. (Т. 4). Москва: Педагогика. / Ushinskij, K.D. (1989). Pedagogicheskie sochineniya [Pedagogical Works]. (Vol. 4). Moscow: Pedagogika [in Russian].

28. Ильичев, Л.Ф., $\quad$ Федосеев, П.Н., $\quad$ Ковалев, С.М. $\quad$ и $\quad$ Панов, В.Г. $\quad$ (Ред.). $\quad$ (1983). Филособбский энциклопедический словарь. Москва: Сов. Энциклопедия / Il'ichev, L.F., Fedoseev, P.N., Kovalev, S.M. \& Panov, V.G. (Red.). (1983). Filosofskij e'nciklopedicheskij slovar' [Philosophic Encyclopedic Dictionary]. Moscow: Sov. e'nciklopediya [in Russian].

29. Щукина, Г.И. (1988). Педагогические проблемь формирования познавательных интересов школьников. Москва: Педагогика / Shhukina, G.I. (1988). Pedagogicheskie problemy formirovaniya poznavatel'nyx interesov shkol'nikov [Pedagogical Problems of Formation Cognitive Interests of Schoolchildren]. Moscow: Pedagogika [in Russian].

30. Яковлев, Е.В. и Яковлева, Н.О. (2006). Педагогическая концепиия: методологические аспекть построения. Москва: Гуманит. изд. центр «ВЛАДОС» / Yakovlev, E.V. \& Yakovleva, N.O. (2006). Pedagogicheskaya koncepciya: metodologicheskie aspekty postroeniya [Pedagogical Concept: Methodological Aspects of Formation]. Moscow: Gumanit. izd. centr «VLADOS» [in Russian].

Дата надходження статті: «28» серпня 2018 р.

Стаття прийнята до друку: «15» листопада 2018 р.

Бучківська Галина - докторант Тернопільського національного педагогічного університету імені Володимира Гнатюка, кандидат педагогічних наук, доцент

Buchkivska Galyna - postdoctoral student of Ternopil Volodymyr Hnatiuk National Pedagogical University, candidate of pedagogical sciences, associate professor

\section{Цитуйте ијю статтю як:}

Бучківська, Г. (2018). Організаційно-педагогічні умови реалізації системи професійної підготовки майбутніх учителів початкових класів на засадах народного декоративно-ужиткового мистецтва. Педагогічний дискурс, 25, 50-62.
Cite this article as:

Buchkivska, G. (2018). Organizational and Pedagogical Sonditions of the System of Professional Education of Primary School Teachers on the Bases of Folk Decorative- and Applied Arts. Pedagogical Discourse, 25, 50-62. 